\title{
РОЗВИТОК УКРАЇНСЬКОЇ НАЦІОНАЛЬНОÏ ІДЕЇ В ПРАЦЯХ М. МІХНОВСЬКОГО
}

Тарасенко Л. Б.

у статті автор висвітлює погляди основоположника та лідера українського самостійництва Миколи Міхновського щодо сутності та реалізації української національної ідеї. Автор зазначає, що гасла, проголошувані Міхновським, вносили революційний перелом у політичну думку української інтелігенції наприкінці XIX - на початку XX cm., оскільки ідея самостійності української держави не в'язалася з законами суспільної еволюції, а обгрунтовувалася Міхновським з огляду на історичні традиції української нації, їі інстинкту самозбереження, невіддільних прав українського народу на незалежне життя. Державну самостійність М. Міхновський вважав головною умовою існування нації, а національну незалежність - національним ідеалом у сфері міжнаціональних відносин. Автором підкреслюється, що, на думку Міхновського, головною причиною нещастя нашої нації є брак націоналізму, тобто національної свідомості, самоповаги, власної гідності, гордості тощо в українському суспільстві, що є надзвичайно актуальним і в наші дні. Міхновський вважав, що, уникаючи начіонального шовінізму пануючих націй, треба плекати здоровий націоналізм поневолених народів, бо саме він $\epsilon$ джерелом творчості і тільки в ньому знаходяться зародки народноі свободи і ясного майбутнього.

Ключові слова: національна ідея, нація, національна свідомість, націоналізм, державна самостійність, національна незалежність.

B cтатье автор освещает взгляды основоположника и лидера украинской самостоятельности Николая Михновского о сущности и путях реализации украинской национальной идеи. Автор отмечает, что лозунги, провозглашаемые Михновским, вносили революционный перелом в политическую мысль украинской интеллигенции в конце XIX - начале XX вв., поскольку идея самостоятельности украинского государства не соотносилась с законами общественной эволюции, а обосновывалась Михновским, исходя из исторических традиций украинской нации, ее инстинкта самосохранения, неотъемлемых прав украинского народа на независимую жизнь. Государственную самостоятельность М. Михновский считал главным условием существования нации, а национальную независимость - национальным идеалом в области межнациональных отношений. Автором подчеркивается, что, по мнению Михновского, главной причиной несчастья нашей нации является недостаток национализма, то есть национального сознания, самоуважения, собственного достоинства, гордости в украинском обществе, что является невероятно актуальным и в наши дни. Михновский считал, что, нужно избегать национального шовинизма господствующих наций и лелеять здоровый национализм порабощенных народов, поскольку именно он является источником творчества и только в нем находятся зачатки народной свободы и ясного будущего.

Ключевые слова: национальная идея, нация, национальное сознание, национализм, государственная самостоятельность, национальная независимость.

In the article the author studies the views of the founder and leader of Ukrainian independence Mykola Mikhnovskyi on the essence and realization of the Ukrainian national idea. The author notes that the slogans proclaimed by Mikhnovskyi made a revolutionary turning point in the political thought of the Ukrainian intelligentsia in the late 19th - early 20th centuries, since the idea of the Ukrainian state independence did not comply with the laws of social evolution but was justified by Mikhnovskyi based on the historical traditions of the Ukrainian nation, its instinct for self-preservation, the inherent rights of the Ukrainian people to independent life. State independence was considered as the main condition for the existence of a nation, and national independence as a national model in the field of international relations. The author emphasizes that, according to Mikhnovskyi, the main cause of our nation's misfortune is the lack of nationalism, i.e. national consciousness, self-respect, self-esteem, pride, etc. in Ukrainian society, which is extremely relevant nowadays. Mikhnovskyi believed that in order to avoid the national chauvinism of the ruling nations, a healthy nationalism of the enslaved peoples should be nurtured because it is the source of creativity that gives the beginning for national freedom and a clear future.

The author emphasizes that Mikhnovskyi viewed the Ukrainian national idea as self-sufficient, separate from the all-Russian one, considered it necessary for Ukraine to gain political independence and achieve unity without regard to possible conflicts and, as soon as possible, the leadership of the Ukrainian intellectual elite in the fight (if necessary) for state independence. Mykola Mikhnovskyi never renounced his ideas and did not serve the Bolsheviks even when repentant statements and cooperation with the Bolsheviks were made by such prominent Ukrainian figures as Volodymyr Vinnychenko, Mikhail Hrushevskyi, and hundreds of other party colleagues.

Key words: national idea, nation, national consciousness, nationalism, state independence, national independence.

Постановка проблеми та їі актуальність. Серед імен лідерів Української національно-демократичної революції 1917-1920 рр. в першу чергу завжди називаються імена Михайла Грушевського, Володимира Винниченка, Сергія Єфремова та інших. Ім'я ж Миколи Міхновського незаслужено відсувається на другий план, у навчальній літературі про нього згадується вкрай недостатньо, хоча саме представникам Української народної партії на чолі з М. Міхновським (самостійникам) передусім належала ініціатива щодо створення Української Центральної Ради.

Аналіз останніх досліджень і публікацій. Окремі аспекти ідейно-політичного спадку та діяльності М. Міхновського досліджували Ю. Вассиян, В. Іванишин, Г. Касьянов, П. Мірчук, М. Сосновський, Ф. Турченко та інші науковці.

Мета статті - 3'ясувати актуальність досить суперечливих, на думку деяких дослідників, засад ідейної спадщини Миколи Міхновського щодо державної самостійності України, незрозумілих його сучасникам,

Тарасенко Л. Б., 2019 
оскільки його ідеї значно випереджали час та й сьогодні залишаються злободенними для розуміння карколомних подій сучасної української історії.

Виклад основного матеріалу. На формування самостійницьких поглядів Міхновського мало значний вплив сімейне середовище. Наш сучасник, київський журналіст Станіслав Міхновський, правнук старшого брата М. Міхновського Юрія (сам Микола Міхновський нащадків не залишив) досліджує історію своєї сім'ї. Прадід та його брати народилися в сім'ї сільського священика отця Івана, церква якого знаходилася біля маєтку Миколи Марковича. Своїх дітей Іван віддавав у світські навчальні заклади, незважаючи на традицію духовної освіти у сім'ї. Сини Міхновського закінчували прилуцьку гімназію, а згодом - Київський університет. Родина Міхновських спілкувалася з найвидатнішими постатями українського національного руху. Завдяки близькості до Марковичів зналася з Тарасом Шевченком. I хоча сам М. Міхновський народився через певний час після смерті Т. Шевченка (у 1873 р.), багато чув розповідей про нього і навіть сфотографувався у воєнній формі, фактично копіюючи відомий шевченківський образ [1].

Суспільно-політичну діяльність М. Міхновський почав рано. Маючи 18 років від народження, він став одним із ініціаторів створення таємного «Братства тарасівців» у 1891 р. , діяльність якого було припинено репресивними заходами самодержавства. Після закінчення університету він працював адвокатом у Харкові, прославився захистом учасників селянських заворушень [2, с. 134].

На Шевченківських святах 19 лютого 1900 р. у Полтаві та 26 лютого 1900 р. у Харкові М. Міхновський, якому було лише 27 років, виголосив промови, що були покладені в основу програмної політичної декларації Революційної української партії «Самостійна Україна» і містили обґрунтування ідеї незалежної української держави.

Гасла, що проголошувалися в «Самостійній Україні», вносили революційний перелом у політичну думку тогочасної української інтелігенції. Ідея самостійності української держави не в'язалася з «законами суспільної еволюції», а обґрунтовувалася Міхновським, виходячи з історичних традицій української нації, їі інстинкту самозбереження, невіддільних прав українського народу на незалежне життя.

М. Міхновський виступав за повернення українцям прав, визначених Переяславською радою 1654 р., за розширенням впливу на етнографічну українську територію: «Одна, єдина, нероздільна, вільна самостійна Україна від Карпат аж по Кавказ». Державну самостійність М. Міхновський вважав головною умовою існування нації, а національну незалежність - національним ідеалом у сфері міжнаціональних відносин. На думку Міхновського, самостійність можна було вибороти силою зброї. Він виступив проти марксистської теорії класової боротьби, наголосивши, що не класи, а нації стають до революційних змагань.

У Харкові промова викликала у присутніх шок, а потім переляк. І це не дивно, бо у тодішній колонії двох імперій більшість українських інтелектуалів (і деякий час навіть Леся Українка і Дмитро Донцов!) вірили в соціалізм і сподівалися на майбутню демократичну федеративну Російську республіку. Як бачимо, політична думка Миколи Міхновського линула набагато попереду думок його сучасників, навіть багатьох однопартійців, які згодом виступили із критикою брошури
М. Міхновського, вважаючи їі твердження помилковими та шкідливими, «надиханими крайнім шовінізмом» [3].

Міхновський розглядав українську національну ідею як самодостатню, відокремлену від загальноросійської, вважав за необхідне здобуття Україною політичної незалежності та досягнення соборності без огляду на можливі конфлікти і в якнайшвидший час, лідерство української інтелектуальної еліти в боротьбі (коли треба, то й збройній) за державну незалежність. На думку М. Міхновського, «народ має право жити тільки тоді, коли він має силу жити».

Міхновський проголошує ідеї, на перший погляд, близькі до націонал-соціалізму, наприклад: «Україна для українців...», хоча необхідно розуміти ці слова не $з$ позиції сьогодення, а того часу, оскільки тоді український народ - один із найбільших народів Європи - не мав власної державності та був розірваний між імперіями. Політолог і літератор Василь Іванишин висловлює таку думку про цей лозунг Міхновського: «Гасло «Україна для українців» має не реакційний і не ксенофобський, а національно-захисний характер. Інша річ, що, на думку багатьох великих «інтернаціоналістів», українці не мають ніякого права захищати свої національні інтереси, бо це може спричинити певні труднощі для тих, що звикли розглядати їх як покірну робочу худобину, котра має право жити і їсти, щоб могла працювати на чергового «благодійника», але ж не більше!.. » [4].

У публіцистиці 1905 р. «Націоналізм і космополітизм» Міхновський наголошує на відмінності націоналізму (національного шовінізму) пануючих націй як системи винародовлення i націоналізму гноблених народів, який він розглядає як захист права боротися за своє людське «я». На думку Міхновського, націоналізм пануючих націй під гаслами космополітизму відбирає останні сили з націй поневолених - їхню інтелігенцію, націоналізм поневолених націй $€$ джерелом історичної творчості, несе в собі зародки народної свободи, має своїм продовженням і розвитком ідеї гуманізму й космополітизму. Здоровий націоналізм, стверджував Міхновський, покликує до історичного життя нові народи, веде до розпаду приречених історією імперій. у бракові такого націоналізму серед широкого загалу українців Міхновський бачить основну причину нещасть своєї нації. Головними опонентами Міхновського $€$ не «чужинці», а «українофіли, що виробили релігію лояльності», українська інтелігенція, яка в попередніх своїх поколіннях не узгоджувала свої інтереси з інтересами народу, зраджувала, покидаючи його в найгірші часи. Ї̈̈ репрезентанти «надали українофільству характер недоношеної розумом етнографічної теорії». Саме «українофіли» зробили український рух чимось смішним і ганебним і тим самим відштовхнули від українства «цілу молоду Україну». Без інтелектуального та чуттєвого резонування чергового молодого покоління на політичний зміст національної ідеї державне унезалежнення України неможливе [5, с. 161-162].

Самостійництво Міхновського було для тодішнього українського суспільства незрозумілим. По-перше, своєю увагою до української державницької традиції, до свободи і прав особи, до «стародавньої культурності української нації». По-друге, своєю подібністю до тодішніх національних рухів в інших центральноєвропейських колоніях чотирьох імперій. Власне, «Само- 


\section{Актуальні проблеми історико-правової та міжнародно-правової науки}

стійна Україна» i починається констатацією переходу тих визвольних рухів до свого завершального етапу - «уоружених повстань зневолених націй проти націй-гнобителів» [3].

«Ми йдемо до повстання, до оружного повстання за визволення українського народу з під економічного та національного рабства, - говориться в праці. ... Ми виходимо на боротьбу за інтереси всього народу українського <...> Повстання се єдина наша оборона i <...> ми тільки боронимось, а не нападаємо, <...> бо ми підтоптані й поневолені, бо нашому життю, цілій будутччині нашого народу загрожує смерть <...> тоді, коли чужинці, пани наші аж тонуть у розкошах та в золоті». У нас «віднято право на працю, право на освіту на мові нашій, право на розвит культурний». Причини зневоленого становлення українців Міхновський бачив в експлуатації чужинців, яким належали «всі добра на Україні». «Ціла купа народів: москалі, ляхи, німці, мадяри, - відзначала «Самостійна Україна», - сидять на нашому народові як паразити, їдять хліб, зароблений крівавим його потом, розкошують у країні, де тубольців повернуто в рабів - цілий нарід рабів - і не хочуть признати за українцями їхніх прав, крім права вмерти [6, с. 36].

У Києві у липні 1917 року під проводом М. Міхновського почалося повстання «самостійників», яких обурив зміст II Універсалу Української Центральної Ради. Вони вимагали від Центральної Ради негайного проголошення незалежності України. Але Центральна Рада не лише відкинула цю вимогу, але й за допомогою російських військ придушила повстання «самостійників», про що Володимир Винниченко - голова Генерального Секретаріату, доповів російському Тимчасовому уряду. Частина «самостійників» була ув'язнена, а частина, у тому числі й Міхновський, відправлена на фронт. А вже в січні 1918 р. та ж сама Центральна Рада проголосила незалежність України, але було вже пізно: армії радянської Росії захопили Донбас, Слобожанщину і загалом мало не все Лівобережжя.

У Миколи Міхновського були доволі натягнуті стосунки з більшістю українських діячів. Він був безкомпромісною людиною і дуже не любив дурнів. Він був освічений, знав собі ціну. Був дуже вразливим. Він розумів Україну у своєму баченні. Він наклав на себе руки 1924 року після кількаденних допитів НКВС (за іншою версією, це не було самогубство). Очевидно Міхновський переконався, що подальша боротьба за самостійність України вже неможлива. Оскільки він був сам по собі, то і вирішив цю проблему, як Сократ. Він був самодостатнім і сам вирішував, що робити з Україною - чи продовжувати боротися, чи накласти на себе руки. Він і був «Україна». Міхновський у собі втілив ідею того українського Едему, який він вкладав у поняття самостійної держави [1].
Міхновський вважав, що головна причина нещастя нашої нації - це брак націоналізму (тобто національної свідомості, самоповаги, власної гідності, гордості тощо) в українському суспільстві. Націоналізм - це велетенська і непоборна сила, яка надто яскраво почала проявлятися з XIX віку. Під їі могутнім натиском ламаються, здається, непереможні кайдани, розпадаються великі імперії і з'являються до історичного життя нові народи, що до того часу покірно несли свої рабські обов'язки при чужинцях-переможцях [7].

На його думку, уникаючи національного шовінізму пануючих націй, треба плекати здоровий націоналізм поневолених народів, бо він $\epsilon$ джерело творчості, і тільки в тому заховуються зародки народної свободи і ясної будучності [7].

У зв'язку з цим потрібно вказати на те, що нерідко лунають порівняння сучасних українських патріотів та захисників України з фашистами, нацистами тощо. Г. Касьянов науково некоректним вважає об'єднувати різні націоналізми з різними особливостями «під однією парасолькою». Використовувати щодо українського націоналізму поняття на кшталт «фашизм», «нацизм» та «інтегральний націоналізм», притаманні для Італії, Німеччини та Франції, недопустимо, бо вони не відображатимуть суті явища [8, с. 326].

До останньої хвилини свого життя Микола Міхновський залишався вірним своїм поглядам, не став на службу до більшовиків навіть тоді, коли складали покаянні заяви і ставали до співпраці з ними такі провідні діячі української національно-демократичної революції, як Володимир Винниченко, Михайло Грушевський та сотні інших їхніх партійних колег. Міхновський залишився до смерті вірним наказові національної честі: «Краще впадь, але не зрадь!» [9, с. 123].

Висновки. Варто зауважити, що в Україні немає пам'ятників Миколі Міхновському, його ім'ям не названо вулиці, площі, школи тощо, але самостійницькі ідеї його концепції нації не загубилися в часі й через сто років ввійшли в обіг серед мислячих українців та дали свої плоди. Напередодні Помаранчевої революції (2004р.) ніхто й подумати не міг, що в Україні загалом можливі масові виступи проти консервативної та корумпованої влади. У 2013-2014рр. мало хто думав, що українське суспільство повстане вдруге, та, що важливо, зможе самоорганізуватися для спротиву як сепаратистським настроям, так і зовнішній агресії. Українська нація, яка стрімко формується на наших очах, і зараз, через величезні труднощі, продовжує доводити, що вона хоче бути і буде демократичною. На обох Майданах і на Східному фронті зараз можна відмітити солідарну дію всіх соціальних прошарків і всіх етносів нашої держави, котрим болить Україна й котрим важливо, щоб вона була «самостійна та демократична», а саме це й заповідав свого часу Микола Міхновський. 


\section{Література}

1. Міхновський С. «Це був Гітлер без жахливих наслідків» - правнук розповів про творця українського націоналізму. URL: https://gazeta.ua/articles/history/ _ce-buv-gitler-bez-zhahlivih-naslidkiv-pravnuk-rozpoviv-protvorcya-ukrayinskogo-nacionalizmu/425929. Дата звернення: 28.11.2019.

2. Лисий І. Міхновський Микола Іванович. Філософська думка в Україні: Бібліографічний словник. Київ, 2002. С. 134-135.

3. Пономарьов В. Нероздільна, вільна, самостійна. URL: https://zbruc.eu/node/58778. Дата звернення: 28.11.2019.

4. Іванишин В. Нація. Державність. Націоналізм. Дрогобич : Вид-во «Відродження», 1992. 176 с.

5. Міхновський М. Націоналізм і космополітизм у кн. Націоналізм: антологія / Наук. т-во ім. В'ячеслава Липин- ського ; упоряд. О. Проценко, В. Лісовий ; літ. ред. Л. Білик. Київ : Смолоскип, 2000. 858 с.

6. Міхновський М.І. Самостійна Україна. Київ : Діокор, 2002. 80 c.

7. Міхновський М. Націоналізм - всесвітня сила. URL:https: / bandera.lviv.ua/mykola-mihnovskyj-nacionalizmvsesvitnja-syla/. Дата звернення: 25.11.2019.

8. Касьянов Г. Теорія нації та націоналізму. Київ : Либідь, 1999. 352 с.

9. Мірчук П. Микола Міхновський - апостол української державності. Філадельфія: Т-во укр. студіююч. молоді імені М. Міхновського, 1960. 136 с.

Тарасенко Л. Б., кандидат історичних наук, доцент, професор кафедри теорії та історії держави і права Одеського державного університету внутрішніх справ 